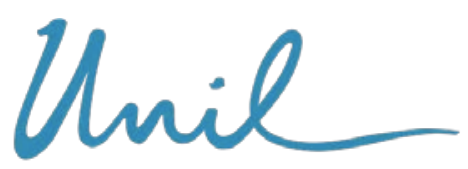

UNIL | Université de Lausanne

Unicentre

$\mathrm{CH}-1015$ Lausanne

http://serval.unil.ch

Year : 2017

\title{
Humoral, T-cell and B-cell immune responses to seasonal influenza vaccine in solid organ transplant recipients receiving anti-T cell therapies
}

\author{
Hequet Delphine
}

Hequet Delphine, 2017, Humoral, T-cell and B-cell immune responses to seasonal influenza vaccine in solid organ transplant recipients receiving anti-T cell therapies

Originally published at: Thesis, University of Lausanne

Posted at the University of Lausanne Open Archive http://serval.unil.ch Document URN : urn:nbn:ch:serval-BIB_714BDAD374EB1

\section{Droits d'auteur}

L'Université de Lausanne attire expressément l'attention des utilisateurs sur le fait que tous les documents publiés dans l'Archive SERVAL sont protégés par le droit d'auteur, conformément à la loi fédérale sur le droit d'auteur et les droits voisins (LDA). A ce titre, il est indispensable d'obtenir le consentement préalable de l'auteur et/ou de l'éditeur avant toute utilisation d'une oeuvre ou d'une partie d'une oeuvre ne relevant pas d'une utilisation à des fins personnelles au sens de la LDA (art. 19, al. 1 lettre a). A défaut, tout contrevenant s'expose aux sanctions prévues par cette loi. Nous déclinons toute responsabilité en la matière.

\section{Copyright}

The University of Lausanne expressly draws the attention of users to the fact that all documents published in the SERVAL Archive are protected by copyright in accordance with federal law on copyright and similar rights (LDA). Accordingly it is indispensable to obtain prior consent from the author and/or publisher before any use of a work or part of a work for purposes other than personal use within the meaning of LDA (art. 19, para. 1 letter a). Failure to do so will expose offenders to the sanctions laid down by this law. We accept no liability in this respect. 
UNIVERSITE DE LAUSANNE - FACULTE DE BIOLOGIE ET DE MEDECINE

Humoral, T-cell and B-cell immune responses to seasonal influenza vaccine in solid organ transplant recipients receiving anti-T cell therapies

\section{THESE}

préparée sous la direction du Docteur Oriol Manuel

et présentée à la Faculté de biologie et de médecine de

l'Université de Lausanne pour l'obtention du grade de

$$
\begin{array}{cc}
\text { BIBLOTHEQUE CANTONALE } \\
\text { DOCTEUR EN MEDECINE } & \begin{array}{c}
\text { ET UNIVERSITAIRE - LAUSANNE } \\
\text { par }
\end{array} \\
12 \text { JUIN } 2017 \\
\text {.THESES }
\end{array}
$$

\section{Delphine HEQUET}

Médecin diplômée de la Confédération Suisse

Originaire de Guggisberg (Berne)

Lausanne 
UNIL | Université de Lausanne

Faculté de biologie

et de médecine

Ecole Doctorale Doctorat en médecine

\section{Imprimatur}

Vu le rapport présenté par le jury d'examen, composé de

Directeur de thèse Monsieur le Docteur Oriol MANUEL

Co-Directeur de thèse

Expert

Vice-Directeur de Monsieur le Professeur John Prior

l'Ecole doctorale

la Commission MD de l'Ecole doctorale autorise l'impression de la thèse de

Madame Delphine HEQUET

intitulée

Humoral, T-Cell and B-Cell immune responses to seasonal influenza viccine in solid organ transplant recipients receiving anti-T cell therapies

Lausanne, le 3 mars 2017

pour Le Doyen

de la Faculté de Biologie et de Médecine

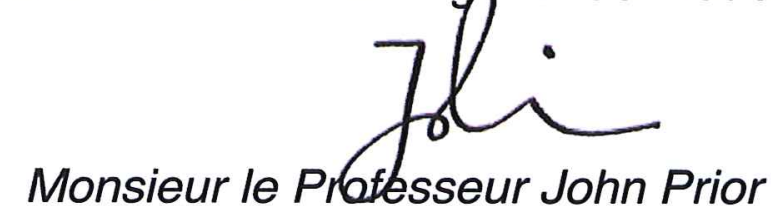

Vice-Directeur de l'Ecole doctorale 


\title{
Humoral, T-cell and B-cell immune responses to seasonal influenza vaccine in solid organ transplant recipients receiving anti-T cell therapies
}

\author{
Rapport de synthèse
}

Les infections par le virus de la grippe causent de nombreuses complications chez les patients transplantés d'organe solide. La vaccination est la stratégie principale pour prévenir une infection par le virus de la grippe. Toutefois, la réponse immunitaire engendrée par le vaccin chez les patients transplantés d'organe reste sous-optimale. La réponse immunitaire est évaluée par le taux d'anticorps spécifiques développés en réponse à la vaccination (immunité humorale). Plusieurs études suggèrent que l'immunité cellulaire serait un meilleur indicateur de la réponse immunitaire. De plus, l'influence des thérapies immunosuppressives anti-cellules T sur la réponse immunitaire après la vaccination contre la grippe est peu documentée.

Durant I'hiver 2012-2013, nous avons mesuré la réponse immunitaire (humorale et cellulaire) au moment de la vaccination contre la grippe et 6 semaines plus tard et avons analysé l'impact de la thérapie anti-cellules T reçue au moment de la greffe (basiliximab ou globuline antithymocytes) sur la réponse immunitaire développée après le vaccin. Dans notre collectif, la réponse immunitaire n'est pas influencée par la thérapie anti-cellule T. Les taux d'anticorps sont significativement plus élevés 6 semaines après la vaccination. De plus, l'immunité cellulaire T (IFN-y en réponse à influenza) a également augmenté de manière significative après la vaccination. En revanche, l'immunité cellulaire $B$ (cellules mémoires B) n'augmente pas après la vaccination.

En conclusion, on observe une augmentation significative de la réponse humorale et de la réponse cellulaire $T$ après la vaccination contre la grippe. En revanche, il n'y a pas d'augmentation de la réponse cellulaire B. De plus, la réponse immunitaire n'est pas influencée par le traitement anti-cellules $T$ reçu au moment de la greffe. 


\title{
Humoral, T-cell and B-cell immune responses to seasonal influenza vaccine in solid organ transplant recipients receiving anti-T cell therapies ${ }^{\text {is }}$
}

\author{
Delphine Héquet ${ }^{\mathrm{a}, \mathrm{b}, *}$, Manuel Pascual ${ }^{\mathrm{a}}$, Sarah Lartey ${ }^{\mathrm{c}}$, Rishi D. Pathirana ${ }^{\mathrm{c}}$, Geir Bredholt $^{\mathrm{c}}$, \\ Katja Hoschler $^{\mathrm{d}}$, Roger Hullin ${ }^{\mathrm{e}}$, Pascal Meylan ${ }^{\mathrm{b}, \mathrm{f}}$, Rebecca J. Cox ${ }^{\mathrm{c}, \mathrm{g}, \mathrm{h}, 1}$, Oriol Manuel ${ }^{\mathrm{a}, \mathrm{b}, 1}$ \\ a Transplantation Center, University Hospital (CHUV) and University of Lausanne, Lausanne, Switzerland \\ ${ }^{\mathrm{b}}$ Infectious Diseases Service, University Hospital (CHUV) and University of Lausanne, Lausanne, Switzerland \\ c Influenza Centre, Department of Clinical Science, University of Bergen, Norway \\ d Public Health England, Microbiology Services Colindale, London, United Kingdom \\ e Division of Cardiology, University Hospital (CHUV) and University of Lausanne, Lausanne, Switzerland \\ ${ }^{\mathrm{f}}$ Institute of Microbiology, University Hospital (CHUV) and University of Lausanne, Lausanne, Switzerland \\ ${ }^{g}$ Department of Research and Development, Haukeland University Hospital, Bergen, Norway \\ h Jebsen Centre for Influenza Vaccine Research, University of Bergen, Norway
}

\section{A R T I C L E I N F O}

\section{Article history:}

Received 16 December 2015

Received in revised form 29 April 2016

Accepted 9 May 2016

Available online 21 May 2016

\section{Keywords:}

Viral infection

Biological agents

Immunogenicity

Induction

Prevention

\begin{abstract}
A B S T R A C T
Background: We analyzed the impact of the anti-T-cell agents basiliximab and antithymocyte globulins (ATG) on antibody and cell-mediated immune responses after influenza vaccination in solid-organ transplant recipients.

Methods: 71 kidney and heart transplant recipients (basiliximab [ $n=43]$ and ATG $[n=28]$ ) received the trivalent influenza vaccine. Antibody responses were measured at baseline and 6 weeks post-vaccination by hemagglutination inhibition assay; T-cell responses were measured by IFN- $\gamma$ ELISpot assays and intracellular cytokine staining (ICS); and influenza-specific memory B-cell (MBC) responses were evaluated using ELISpot.

Results: Median time of vaccination from transplantation was 29 months (IQR 8-73). Post-vaccination seroconversion rates were $26.8 \%$ for $\mathrm{H} 1 \mathrm{~N} 1,34.1 \%$ for $\mathrm{H} 3 \mathrm{~N} 2$ and $4.9 \%$ for influenza $\mathrm{B}$ in the basiliximab group and $35.7 \%$ for $\mathrm{H} 1 \mathrm{~N} 1,42.9 \%$ for $\mathrm{H} 3 \mathrm{~N} 2$ and $14.3 \%$ for influenza B in the ATG group ( $p=0.44, p=0.61$, and $p=0.21$, respectively). The number of influenza-specific IFN- $\gamma$-producing cells increased significantly after vaccination (from 35 to $67.5 \mathrm{SFC} / 10^{6} \mathrm{PBMC}, p=0.0007$ ), but no differences between treatment groups were observed $(p=0.88)$. Median number of IgG-MBC did not increase after vaccination $(\mathrm{H} 1 \mathrm{~N} 1, p=0.94$; H3N2 $p=0.34$; B, $p=0.79$ ), irrespective of the type of anti-T-cell therapy.

Conclusions: After influenza vaccination, a significant increase in antibody and T-cell immune responses but not in $\mathrm{MBC}$ responses was observed in transplant recipients. Immune responses were not significantly different between groups that received basiliximab or ATG.
\end{abstract}

(c) 2016 Elsevier Ltd. All rights reserved.
Abbreviations: ATG, antithymocyte globulins; SOT, solid organ transplant; HI, hemagglutination inhibition; MBC, memory B-cell; ICS, intracellular cytokine staining; MPA, mycophenolic acid; SFC, spot-forming cells; IL-2, interleukin-2; IFN- $\gamma$, interferon- $\gamma$; TNF- $\alpha$, tumor necrosis factor $\alpha$.

is This work was presented at the World Transplant Congress, San Francisco, July 26th-31st 2014 (abstracts \# 1205 and \#2876). It was rewarded by a young investigator award.

* Corresponding author at: Infection Control, University Hospital and University of Lausanne, MP18/422, CHUV, Lausanne, Switzerland. Tel.: +41 21314 1288; fax: +412131410262 .

E-mail address: delphine.hequet@chuv.ch (D. Héquet).

1 Co-senior authorship.

\section{Introduction}

Influenza is associated with significant morbidity in solidorgan transplant (SOT) recipients [1,2]. While the main preventive strategy against influenza after transplantation remains annual influenza vaccination [3], the immunogenicity and efficacy of influenza vaccine are suboptimal in this population [4]. This is mainly due to the use of immunosuppressive drugs to avoid rejection in transplant recipients, which inhibit mainly T-cell, but also B-cell, activation. The immunosuppressive regimen usually consists of an induction therapy at time of transplantation, either basiliximab or antithymocyte globulins (ATG) [5] followed by maintenance immunosuppression [6]. Basiliximab is a monoclonal 
antibody that binds the $\alpha$-chain (CD25) of the interleukin 2 receptor, inhibiting T-cell activation, but without a depleting effect on lymphocytes [7]. On the other hand, ATG contains polyclonal IgG from rabbits immunized with human thymocytes, which blocks T-cell membrane proteins causing prolonged T-cell depletion [8]. Despite lower T-cell counts in patients receiving ATG, humoral responses to seasonal influenza vaccine were similar in kidney transplant recipients receiving either ATG or basiliximab as induction therapy [9].

A significant challenge for assessing the efficacy of influenza vaccine is the lack of validated markers of vaccine responses in immunocompromised patients. The hemagglutination inhibition (HI) assay correlates with vaccine protection in immunocompetent patients, but it remains unclear whether the HI assay can predict protection against influenza in patients receiving immunosuppressive drugs, such as in SOT recipients [10-12]. Cell-mediated immunity appears to be a promising predictor of vaccine response [13-15]. Induction of T-cell immune responses, mediated by CD4+ and $\mathrm{CD} 8+$, is a crucial step for reducing the severity of symptoms and for preventing complications of influenza in the general population $[16,17]$. Granzyme B levels, a marker for T-cell responses, have been correlated with clinical vaccine protection against influenza in the elderly [16]. Another key component of the immune response to influenza vaccination is antigen-specific longlived plasma cells and memory B-cells (MBC). MBC are generated in response to $\mathrm{T}$-dependent antigens and they differentiate into plasma cells secreting high-affinity antibodies upon re-exposure to antigen, therefore increasing the effectiveness of the antibody responses [18].

There is little information about the impact of immunosuppressive regimens on T-cell and B-cell responses elicited by influenza vaccination. In particular, only few studies have assessed the influence of induction therapy on immune responses after organ transplantation $[19,20]$. We therefore studied humoral, T-cell, and $B$-cell responses after influenza vaccination in a prospective cohort of SOT recipients receiving basiliximab or ATG.

\section{Materials and methods}

\subsection{Study population and study design}

Adult SOT recipients were recruited prospectively from the outpatient clinic of the Transplantation Center of the University Hospital of Lausanne, Switzerland, during the 2012-2013 influenza season. Patients were included if they were scheduled to receive the influenza vaccine, had undergone kidney or heart transplantation more than 3 months before vaccination, had received induction therapy with basiliximab or ATG, and were 18 years or older. The exclusion criteria were documented egg allergy, an acute febrile illness within the 7 days preceding vaccination, the occurrence of an episode of clinical or biopsy-proven acute rejection 4 weeks before vaccination, and previous life-threatening reaction to influenza vaccine. The study was approved by the local institutional review board and an informed consent was signed by all the participating patients.

At enrollment (day 0, pre-vaccination), a baseline blood sample was collected to measure the titers of antibody levels against each viral strain, specific T-cell and B-cell immune responses, as well as the $\mathrm{CD}^{+}$and $\mathrm{CD}^{+}$T-cell counts. Patients then received a single $0.5 \mathrm{ml}$ intramuscular injection of the trivalent influenza vaccine in the deltoid muscle of the non-dominant arm. In this study, we used the non-adjuvanted, inactivated trivalent influenza vaccine Mutagrip ${ }^{\circledR}$ (Sanofi-Pasteur MSD, Baar, Switzerland) or Influvac $^{\circledR}$ (Abbott AG, Switzerland). These vaccines contain $15 \mu \mathrm{g}$ of HA antigen from each viral strain [A/California/7/2009
(H1N1)pdm09-like virus, A/Victoria/361/2011 (H3N2)-like virus, and $\mathrm{B} / \mathrm{Wisconsin} / 1 / 2010$-like virus]. At 6 weeks after vaccination, a second blood sample was collected to measure the humoral and cellular immune responses to the vaccine. Patients were followed up for 6 months for the development of influenza infection and acute allograft rejection.

\subsection{Immunosuppressive protocol}

Kidney transplant recipients received per protocol induction therapy with basiliximab at $20 \mathrm{mg}$ at days 0 and day 4 posttransplant. In case of re-transplantation or high immunologic risk (defined as the presence of anti-HLA antibodies or a panel reactive antibodies (PRA) of $>50 \%$ ), ATG (Thymoglobulin ${ }^{\circledR}$, Sanofi Genzyme, Marcy L'Etoile, France) was administered at doses of $1-1.5 \mathrm{mg} / \mathrm{kg} / \mathrm{day}$ for 3-4 days. In case of delayed graft function [6], basiliximab was discontinued and ATG was initiated using the same regimen described above. A daily bolus of intravenous methylprednisolone was given during the first 3 days after transplantation. Initial maintenance immunosuppressive therapy consisted of tacrolimus, mycophenolic acid (MPA, either as mycophenolate mofetil or sodium) and steroids. Heart transplant recipients received per protocol induction therapy with ATG (same doses as above) and maintenance therapy with cyclosporine or tacrolimus, MPA, and steroids. In case of transplantation in patients with a ventricular assist device implanted pre-transplant, induction therapy with basiliximab instead of ATG was used.

For the purposes of this study, patients were included in the ATG group if they have received at least one dose of ATG for (1) induction therapy or (2) in case of delayed graft function or (3) for treatment of acute rejection (irrespective of whether they had previously received basiliximab). All other patients were included in the basiliximab group.

\subsection{Laboratory assays}

Total lymphocyte and lymphocyte subpopulation cell counts were performed at the Laboratory of Immunology, CHUV; Lausanne, Switzerland, using a FacsCalibur flow cytometrer (BD Bioscience, San Jose, CA, USA).

The hemagglutinin inhibition ( $\mathrm{HI}$ ) assay was used to analyze the antibody response and was performed at the Health Protection England (HPE) in London, United Kingdom, according to standardized methods [21]. Serum samples were tested with the use of 1:2 serial dilutions at an initial dilution of $1: 10$. Samples with a negative result for the hemagglutinin antibody were assigned a titer of 1:5. Specimens were tested in duplicate, and results were expressed by the geometric mean titer for analysis.

Peripheral blood mononuclear cells (PBMC) were isolated by density gradient Ficoll separation. PBMCs were then washed, counted and frozen in fetal bovine serum (FBS) containing 10\% dimethyl sulfoxide (DMSO) at $-80^{\circ} \mathrm{C}$ overnight and then transferred to liquid nitrogen until use. Lymphocytes were defrosted and rested overnight in RPMI medium with $10 \%$ fetal calf serum at $37^{\circ} \mathrm{C}$. T-cell responses were assessed by detecting IFN- $\gamma$ production, after stimulation with the 3 viral strains, using a standard ELISpot assay [22-24]. Briefly, cells (400,000 cells/well) in RPMI medium with $10 \%$ fetal calf serum were cultured on a pre-coated IFN- $\gamma$ plates (Mabtech AB, Sweden) with negative control (medium alone) or influenza antigens $(5 \mu \mathrm{g} / \mathrm{ml}$ of split virus vaccine of each influenza strain A/H1N1, A/H3N2, B strain). After overnight incubation $\left(37^{\circ} \mathrm{C}\right.$, $5 \% \mathrm{CO}_{2}$ ) the assay was developed according to the manufacturer's instructions and the plates were read using Immunoscan ${ }^{\mathrm{TM}}$ reader and associated software (CTL-Europe). Results were expressed as spot-forming cells (SFC) $/ 10^{6}$ PBMCs after subtraction of the background value obtained with non-stimulated cells. 
Intracellular cytokine staining (ICS) was performed to measure influenza-specific CD4 Th1 cytokines interleukin-2 (IL-2) and tumor necrosis factor- $\alpha$ (TNF- $\alpha$ ). PBMC were stimulated overnight with a mixture of the three split virus antigens in the vaccine, $\mathrm{A} / \mathrm{H} 1 \mathrm{~N} 1, \mathrm{~A} / \mathrm{H} 3 \mathrm{~N} 2$ and $\mathrm{B}(2.5 \mu \mathrm{g} / \mathrm{ml}$ of each protein $)$ in the presence of Brefeldin A, Monensin and anti-CD49d antibodies (BD Biosciences, USA). After ovenight stimulation, cells were stained for intracellular cytokines and analyzed on a BD LSRFortessa (BD Biosciences) for the expression of IFN- $\gamma$, IL- 2 and TNF- $\alpha$ from CD $4^{+}$ T-cells $[24,25]$. CD4 ${ }^{+}$T cells were classified on the basis of IFN- $\gamma$, IL-2, and TNF- $\alpha$ secretion as single producers (producing any single cytokine), double producers ( 2 cytokines), and triple producers (all 3 cytokines).

Influenza-specific and total IgG memory B-cell responses were evaluated after a 7 day in vitro stimulation using direct influenzaspecific ELISpot for each of the three viral strains [26]. Total IgG-MBC responses were measured after being stimulated for 7 days with Pokeweed mitogen (Sigma) and ODN-2006 (Integrated DNA Technologies). A total of 50,000 cells/well for detection of influenza specific cells were plated for the B-cell ELISpot. The number of spots counted varied, but ranged from 0 to 100 spots per well.

For both T-cell and B-cell ELISpot lymphocytes from a healthy volunteer were included as a positive control in all assays. The average number of SFC for this individual was 487 IFN- $\gamma$ SFC $/ 10^{6}$ PBMC (for T-cell ELISpot), 624 IgG-MBC/106 PBMC (for H1N1 MBC ELISpot), 494 IgG-MBC/10 6 PBMC (for H3N2 MBC ELISpot), 1156 IgG-MBC $/ 10^{6}$ PBMC (for influenza B MBC ELISpot), and 167750 IgG$\mathrm{MBC} / 10^{6} \mathrm{PBMC}$ (for total IgG-MBC ELISpot).

\subsection{Clinical definitions and outcomes}

The vaccine induced antibody responses were evaluated according to the European Agency for the Evaluation of Medicinal Products [27]. Seroconversion rate was defined as the percentage of patients with $\geq 4$-fold increase in antibody titers against influenza after vaccination. Seroprotection rate was defined as the percentage of patients with an HI after vaccination of 1:40 or more. We use the Beyer correction to take into consideration the presence of prevaccination antibodies in the seroconversion rate [28]. We defined antibody vaccine response as corrected seroconversion to at least one viral strain. As no correlate of protection has been defined, results of the T-cell responses (by IFN- $\gamma$ Elispot and by ICS) and the $M B C$ responses are shown descriptively.

\subsection{Statistical analysis}

The primary endpoint was the seroconversion rate (serological response with a four-fold or greater increase in HI antibody). With a planned sample size of 30 patients per group we expected to have a power of $80 \%$ to detect a difference in the seroconversion rate of $30 \%$ between groups (e.g. $50 \%$ vs. $80 \%$ seroconversion rate in the ATG group $v$ s. basiliximab group). Comparisons between the two groups were performed by the Fisher's exact test in case of categorical variables, and by the Wilcoxon rank test in case of continuous variables. The proportion of serological responders ( $\geq 4$-fold increase in $\mathrm{HI}$ antibody titers) between baseline and 6 weeks after vaccination was compared by the Fisher's exact test. Antibody titers, IFN- $\gamma$ SFC counts, ICS data, and IgG SFC counts between pre and post-vaccination were compared with the Wilcoxon rank test. The Spearman test was used to correlate humoral and cellular immune responses, and T-cell subpopulation counts. All analyses were performed using GraphPad Prism (GraphPad Software, La Jolla, CA, USA). Two-tailed $p$-values $<0.05$ were considered statistically significant.

\section{Results}

\subsection{Baseline characteristics of the study population}

A total of 71 patients were enrolled in the study (64 kidney, 5 heart, 1 heart-kidney, and 1 kidney-pancreas recipient) and received the influenza vaccine. Overall, 43 patients received basiliximab and 28 patients received ATG (14 received only ATG as induction therapy and 14 received ATG after basiliximab, 12 for delayed graft function and 2 to treat an episode of acute rejection). Of note, 66 patients received a subunit virus vaccine and 5 patients a split virus vaccine. Two patients were lost to followup; immunogenicity of the vaccine was therefore assessed in 69 patients. Baseline characteristics are shown in Table 1 . The median of total lymphocyte and $\mathrm{CD} 4^{+} \mathrm{T}$-cell counts were significantly lower in patients who had received ATG induction (909 cells $/ \mathrm{mm}^{3}$ and 313 cells $/ \mathrm{mm}^{3}$, respectively) as compared to patients who had received basiliximab (1466 cells $/ \mathrm{mm}^{3}$ and 667 cells $/ \mathrm{mm}^{3}$, respectively). None of the patients was diagnosed with influenza in the follow-up 6 months after vaccination.

\subsection{Antibody response to influenza vaccine in patients receiving induction therapy}

The HI antibody responses in patients stratified according to induction therapy (basiliximab or ATG) are summarized in Table 2. There was a significant increase after vaccination for all three antigens $(p<0.0001$ for H1N1, $p<0.0001$ for H3N2, and $p<0.0001$ for B). No differences were observed in influenza H1N1 and H3N2 HI titers between the basiliximab and ATG groups 6 weeks after vaccination ( $p=0.89$ for H1N1, and 0.49 for H3N2). The antibody response against influenza B was significantly higher in ATG group, in terms of HI titers (10.33 in the basiliximab group vs. 25.92 in the ATG group, $p=0.007)$ and in the seroprotection rate $(17.1 \% v s$. $50 \%$, respectively, $p=0.007$ ). The Beyer corrected seroconversion rates were $26.8 \%$ for $\mathrm{H} 1 \mathrm{~N} 1,34.1 \%$ for $\mathrm{H} 3 \mathrm{~N} 2$ and $4.9 \%$ for influenza $B$ in the basiliximab group and $35.7 \%$ for $\mathrm{H} 1 \mathrm{~N} 1,42.9 \%$ for $\mathrm{H} 3 \mathrm{~N} 2$ and $14.3 \%$ for influenza B in the ATG group ( $p=0.44, p=0.61$, and $p=0.21$, respectively).

We then analyzed other potential clinical variables that influenced antibody response (defined as corrected seroconversion to at least one viral strain). We did not find any difference in terms of organ transplanted or immunosuppressive regimen. For example, vaccine response was $46.2 \%$ in patients receiving MPA as compared to $52.9 \%$ in patients without MPA $(p=0.78)$, and $54.1 \%$ in patients receiving tacrolimus as compared to $25 \%$ in patients without tacrolimus $(p=0.15)$. MPA dosage did not influence the seroconversion rate after vaccination $(r=-0.17$ for $\mathrm{H} 1 \mathrm{~N} 1, r=0.07$ for $\mathrm{H} 3 \mathrm{~N} 2$ and $r=-0.06$ for influenza B). Median time from transplantation was 25.5 months (range 9-73) in responders as compared to 29 months (range 7-65) in non-responders $(p=0.84)$. Median CD4+ and CD8+ T-cell counts were 498 (range 321-865) cells/ml and 382 (range 233-612) cells/ $\mathrm{ml}$ in responders, and 490 (range 259-744) cells $/ \mathrm{ml}$ and 348 (range 182-648) cells/ml in non-responders, respectively. Lower vaccine responses were not observed in patients with previous allograft rejection ( $n=7$, data not shown).

\subsection{T-cell-mediated immune responses to influenza vaccine}

T-cell-mediated immune responses to influenza vaccine were determined by the IFN- $\gamma$ ELISpot assay after stimulation with a mix of the 3 viral strains in 67 patients and by ICS in 51 patients. The number of patients in whom cell-mediated immunity was assessed varied according to the number of available cells for each patient.

Table 3 and Fig. 1 show the IFN- $\gamma$ response by ELISpot in patients stratified according to the induction regimen received (basiliximab 
Table 1

Baseline characteristics of the study population.

\begin{tabular}{|c|c|c|c|c|}
\hline & All patients $(n=71)$ & Basiliximab $(n=43)$ & Antithymocyte globulin $(n=28)$ & $p$-value \\
\hline Age, median (IQR), yr & $54(46-63)$ & $54(44-63)$ & $54.5(47-64.5)$ & 0.62 \\
\hline Gender (M/F) & $52 / 29$ & $28 / 15$ & $24 / 4$ & 0.06 \\
\hline Time from transplant, median (IQR), month & $29(8-73)$ & $31(10-83)$ & $22(6.25-56.75)$ & 0.23 \\
\hline \multicolumn{5}{|l|}{ Organ transplanted; $n(\%)$} \\
\hline - Kidney & $64(90.2)$ & $40(93)$ & $24(85.7)$ & 0.4 \\
\hline - Heart & $5(7)$ & $3(7)$ & $2(7.1)$ & 1.00 \\
\hline - Heart-kidney & $1(1.4)$ & 0 & $1(3.6)$ & 1.00 \\
\hline - Kidney-pancreas & $1(1.4)$ & 0 & $1(3.6)$ & 1.00 \\
\hline \multicolumn{5}{|l|}{ Underlying disease; $n(\%)$} \\
\hline Kidney transplant recipients & $(n=66)^{\mathrm{a}}$ & $n=40$ & $n=26$ & \\
\hline - ADPKD & $11(16.7)$ & $7(17.5)$ & $4(15.4)$ & 1.00 \\
\hline - Berger disease & $9(13.6)$ & $6(15)$ & $3(11.5)$ & 1.00 \\
\hline - Reflux disease & $7(10.6)$ & $5(12.5)$ & $2(7.7)$ & 0.69 \\
\hline - Alport disease & $6(9.1)$ & $4(10)$ & $1(3.8)$ & 0.64 \\
\hline - Hypertensive nephropathy & $5(7.6)$ & $2(5)$ & $4(15.4)$ & 0.20 \\
\hline - Other & $28(42.4)$ & $16(40)$ & $12(46.2)$ & 0.79 \\
\hline Heart transplant recipients & $(n=6)^{\mathrm{b}}$ & $n=3$ & $n=3$ & 1.00 \\
\hline - Ischemic & $3(50)$ & $2(66.7)$ & $1(33.3)$ & \\
\hline - Hypertrophic cardiomyopathy & $1(16.6)$ & 0 & $1(33.3)$ & \\
\hline - Dilated cardiomyopathy & $1(16.6)$ & 0 & $1(33.3)$ & \\
\hline - Genetic disorder & $1(16.6)$ & $1(33.3)$ & 0 & \\
\hline Previous transplantation, $n(\%)$ & $11(15.5)$ & $7(16.3)$ & $4(14.3)$ & 1.00 \\
\hline \multicolumn{5}{|l|}{ Maintenance immunosuppresion, $n(\%)$} \\
\hline - Prednisone & $48(67.6)$ & $26(60.5)$ & $22(78.6)$ & 0.12 \\
\hline - Tacrolimus & $63(88.7)$ & $36(83.7)$ & $27(97.4)$ & 0.13 \\
\hline - Cyclosporine & $7(9.9)$ & $7(16.3)$ & 0 & 0.0001 \\
\hline - mTOR inhibitor & $1(1.4)$ & 0 & $1(3.6)$ & 0.39 \\
\hline - MPA & $53(74.6)$ & $33(76.7)$ & $20(71.4)$ & 0.78 \\
\hline - Azathioprine & $12(16.9)$ & $8(18.6)$ & $4(9.3)$ & 0.75 \\
\hline Allograft rejection before vaccination, $n(\%)$ & $7(9.8)$ & $5(11.6)$ & $2(7.1)$ & 0.69 \\
\hline - Acute cellular rejection & $5(7.0)$ & $3(7.0)$ & $2(7.1)$ & 1.00 \\
\hline - Chronic humoral rejection & $2(2.8)$ & $2(4.6)$ & 0 & 0.51 \\
\hline Rituximab treatment, $n(\%)$ & $2(2.8)$ & 0 & $2(7.1)$ & 0.15 \\
\hline 2011-2012 influenza vaccine, $n(\%)$ & $61(85.9)$ & $38(88.4)$ & $23(82.1)$ & 0.5 \\
\hline Creatinine level, median (IQR), $\mu \mathrm{M} / \mathrm{l}$ & $133(69-154)$ & $129(103-147)$ & $138.5(103-152)$ & 0.31 \\
\hline \multicolumn{5}{|l|}{ Leucocyte count, median (IQR), cells $/ \mathrm{mm}^{3}$} \\
\hline - Total lymphocytes & $1251(259-1773)$ & $1466(959-2216)$ & $909(621.8-1533)$ & 0.002 \\
\hline - CD4+ lymphocytes. & $497(299-1670)$ & $667(497-914)$ & $313(200.5-389.5)$ & $<0.0001$ \\
\hline - CD8 ${ }^{+}$lymphocytes & $380(229-1654)$ & $410(268-701)$ & $248(191-500.5)$ & 0.05 \\
\hline
\end{tabular}

ADPKD: autosomal dominant polycystic kidney disease, MPA: mycophenolic acid.

a Including kidney, kidney-pancreas, and heart-kidney transplant recipients.

b Including heart and heart kidney transplant recipients.

Table 2

Antibody response by hemagglutination inhibition assay before and after influenza vaccination for each viral strain according to induction therapy.

\begin{tabular}{|c|c|c|c|c|}
\hline & All patients $(n=69)$ & Basiliximab $(n=41)$ & Antithymocyte globulin $(n=28)$ & $p$-value \\
\hline \multicolumn{5}{|c|}{ Geometric mean titer $(95 \% \mathrm{CI})$} \\
\hline \multicolumn{5}{|c|}{ • Week 0} \\
\hline Influenza A H1N1 & $30.79(21.3-44.52)$ & $28.76(18.03-45.87)$ & $34.03(18.05-64.15)$ & 0.72 \\
\hline Influenza A H3N2 & $107.6(92.27-125.5)$ & $98.87(80.46-121.5)$ & $121.9(96.06-154.6)$ & 0.16 \\
\hline Influenza B & $9.65(7.58-12.28)$ & $7.56(6.07-9.41)$ & $13.8(8.45-22.51)$ & 0.07 \\
\hline \multicolumn{5}{|l|}{ • Week 6} \\
\hline Influenza A H1N1 & $54.88(39.03-77.17)^{*}$ & $53.77(35.36-81.76)^{*}$ & $56.55(30.79-103.8)^{*}$ & 0.89 \\
\hline Influenza A H3N2 & $157(134.7-182.9)^{*}$ & $147.1(122.3-176.8)^{*}$ & $172.7(131.2-227.3)^{*}$ & 0.49 \\
\hline Influenza B & $15.01(11.09-20.30)^{*}$ & $10.33(7.67-13.91)^{*}$ & $25.92(14.68-45.78)^{*}$ & 0.007 \\
\hline \multicolumn{5}{|l|}{ Seroprotection rate, $n$ (\%) } \\
\hline \multicolumn{5}{|l|}{ - Week 0} \\
\hline Influenza A H1N1 & $32(46.4)$ & $19(46.3)$ & $13(46.4)$ & 1.00 \\
\hline Influenza A H3N2 & $67(97.1)$ & $39(95.1)$ & $28(100)$ & 0.51 \\
\hline Influenza B & $13(18.8)$ & $3(7.3)$ & $10(35.7)$ & 0.03 \\
\hline \multicolumn{5}{|l|}{ • Week 6} \\
\hline Influenza A H1N1 & $42(60.9)$ & $26(63.4)$ & $16(57.1)$ & 0.80 \\
\hline Influenza A H3N2 & $69(100)$ & $41(100)$ & $28(100)$ & 1.00 \\
\hline Influenza B & $21(30.4)$ & $7(17.1)$ & $14(50)$ & 0.007 \\
\hline \multicolumn{5}{|c|}{ Seroconversion rate, $n$ (\%) } \\
\hline Influenza A H1N1 & $13(18.8)$ & $10(24.4)$ & $3(10.7)$ & 0.21 \\
\hline Influenza A H3N2 & $2(2.9)$ & $2(4.9)$ & $0(0)$ & 0.51 \\
\hline Influenza B & $11(15.9)$ & $4(9.8)$ & $7(25)$ & 0.10 \\
\hline \multicolumn{5}{|c|}{ Beyer corrected seroconversion rate, $n(\%)$} \\
\hline Influenza A H1N1 & $21(30.4)$ & $11(26.8)$ & $10(35.7)$ & \\
\hline Influenza A H3N2 & $26(37.7)$ & $14(34.1)$ & $12(42.9)$ & 0.44 \\
\hline Influenza B & $6(8.7)$ & $2(4.9)$ & $4(14.3)$ & 0.61 \\
\hline
\end{tabular}

${ }^{*} p<0.001$ between before and after vaccination for all three viral strains. 
Table 3

T-cell-mediated immune response by IFN- $\gamma$ secretion before and after influenza vaccination after stimulation with all three viral strains.

\begin{tabular}{|c|c|c|c|c|}
\hline & All patients $(n=67)$ & Basiliximab $(n=40)$ & Antithymocyte globulin $(n=27)$ & $p$-value \\
\hline \multicolumn{5}{|c|}{ IFN- $\gamma$ median SFC (IQR), SFC $/ 10^{6}$ PBMC } \\
\hline - Week 0 & $35(11.3-81.3)$ & $43.1(10.3-81.3)$ & $32.5(12.5-73.8)$ & 0.59 \\
\hline - Week 6 & $67.5(27.5-131.3)^{*}$ & $66.9(27.5-132.8)^{* *}$ & $76.3(27.5-131.3)^{* * *}$ & 0.88 \\
\hline
\end{tabular}

${ }^{*} p=0.0007,{ }^{* *} p=0.05,{ }^{* * *} p=0.004$ before and after vaccination.

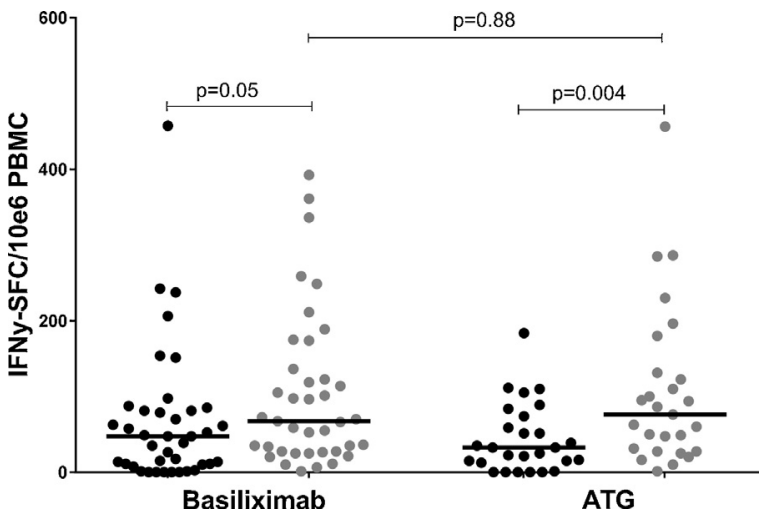

Fig. 1. T-cell immune response, evaluated by IFN- $\gamma$ secretion (ELISPOT), according to induction therapy (basiliximab or ATG). Data before vaccination are shown in black and data after vaccination are represented in gray. Each dot represents one individual and bars show the median.

[ $n=40]$ or ATG $[n=27])$. While IFN- $\gamma$ secretion increased in both groups six weeks after vaccination ( $p=0.05$ for the basiliximab group and 0.004 for the ATG group), the differences between the two groups were not statistically significant. The use of a particular drug for maintenance immunosuppression did not influence the IFN- $\gamma$ secretion after vaccination (data not shown). In particular, differences in T cell-mediated immune responses were not observed according to the dose of MPA received.

Fig. 2A shows the frequencies of influenza-specific CD4+ Tcells secreting either a single Th1 cytokine (IFN- $\gamma$, TNF- $\alpha$, or IL-2) or simultaneously producing more than one cytokine (multifunctional cells) before and after vaccination in all 51 patients. The percentage of IFN- $\gamma(p=0.01)$ and TNF- $\alpha(p=0.006)$ single-cytokine producing cells was significantly higher after vaccination compared with pre-vaccination levels, as well as the percentage of multifunctional T-cells, with a significant increase in cells producing
2 cytokines (IL-2 $\left.2^{+} \mathrm{TNF}-\alpha^{+}, p=0.02\right)$ and all 3 cytokines (IFN- $\gamma^{+}$ IL- $2^{+}$TNF- $\left.\alpha^{+}, p=0.01\right)$. When we looked at the multifunctional CD4+ T cell responses in the basiliximab $[n=30]$ and the ATG $[n=21]$ groups, we observed a higher percentage of specific CD4+ T-cells expressing all three cytokines in the ATG group (median of $0.021 \%$ ), as compared to in the basiliximab group (median of $0.010 \%$, $p=0.14$ ), although the differences were not statistically significant (Fig. 2B).

\subsection{B-cell-mediated immune responses to influenza vaccine}

We then assessed the total and influenza MBC responses by ELISpot in 64 patients. Overall, no significant increase in the median number of IgG-MBC/10 $10^{6} \mathrm{PBMC}$ was observed against any of the three viral strains $(\mathrm{H} 1 \mathrm{~N} 1, p=0.94$; $\mathrm{H} 3 \mathrm{~N} 2, p=0.34$; influenza $B$, $p=0.79$ ) (Fig. 3A). The total IgG MBC responses did not increase after vaccination either $(p=0.19)$ (Fig. 3B).

$\mathrm{MBC}$ responses were assessed in 38 patients in the basiliximab group and 26 patients in the ATG group (Fig. 4). IgG-MBC/106 PMBC levels after vaccination were generally lower in the ATG group as compared to the basiliximab group for each of the three viral strains, although these differences were not statistically significant. The post-vaccination total IgG responses were significantly lower in the ATG group compared with the group that received basiliximab (6327 vs. 11905 IgG-MBC/10 6 PBMC, $p=0.05$ ).

The B-cell responses were not influenced by the maintenance immunosuppressive regimen received (data not shown). However, we observed a positive correlation between $\mathrm{CD} 4^{+} \mathrm{T}$-cell count and influenza A H1N1 IgG MBC response $(r=0.34$ and $p=0.005)$ and with total IgG MBC response $(r=0.31$ and $p=0.01)$ (Supplementary Fig. 1). We also assessed the influence of influenza vaccination on the previous year on $\mathrm{MBC}$ responses. $\mathrm{MBC}$ responses were not statistically different in patients with or without previous influenza vaccination ( $30 v s .0$ for $\mathrm{H} 1 \mathrm{~N} 1$ [ $p=0.37], 40 v s .5$ for $\mathrm{H} 3 \mathrm{~N} 2$ [ $p=0.24]$, and $60 v s$. 15 for $\mathrm{B}[p=0.64]$, respectively).

\section{A. Influenza specific CD4+T-cell response}

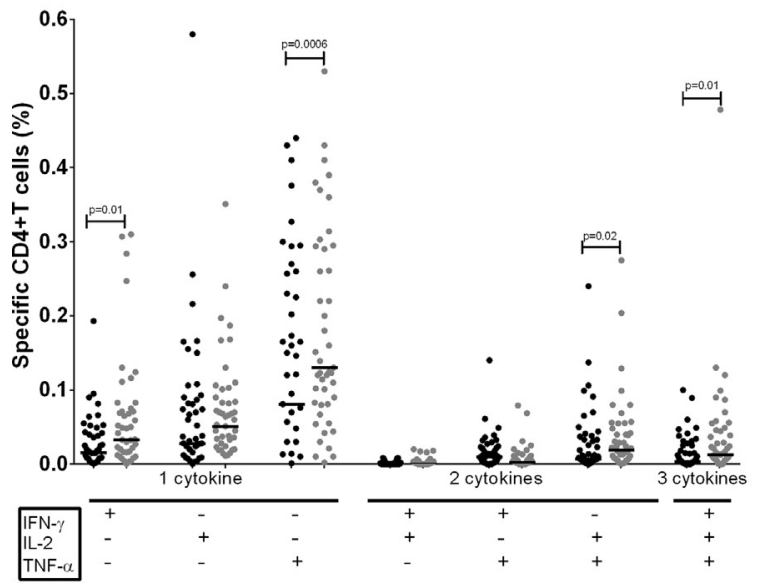

\section{B. Multifunctional CD4+ T-cell response}

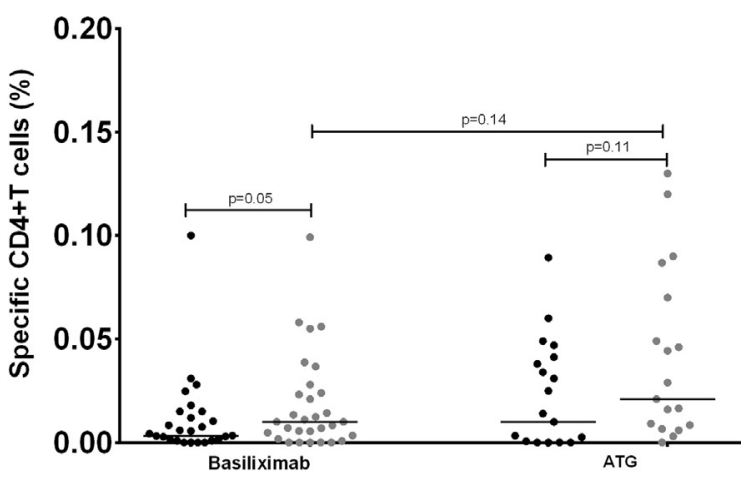

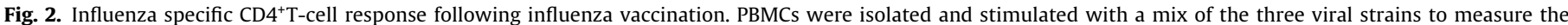

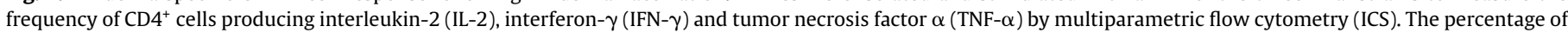
specific $\mathrm{CD}^{+}$cells before vaccination is shown in black and data after vaccination are represented in gray. Each dot represents one individual and bars show the median. 
A. Influenza-specific IgG memory B-cell response

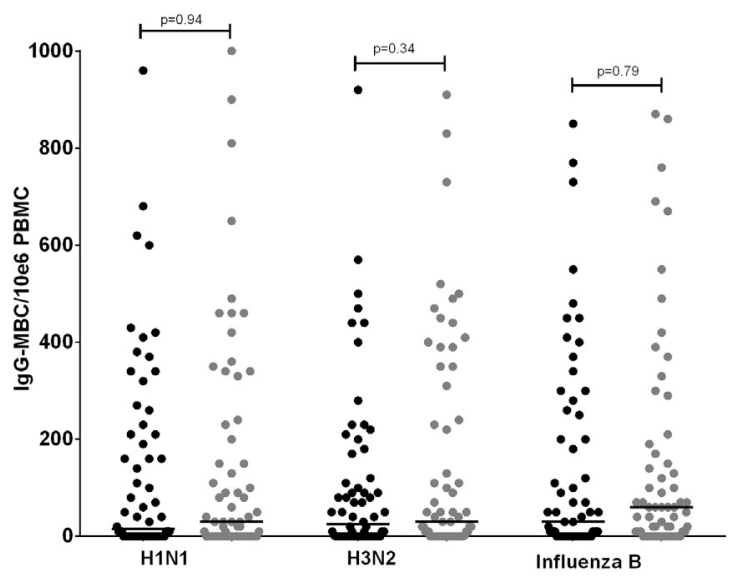

B.Total IgG memory B-cell response

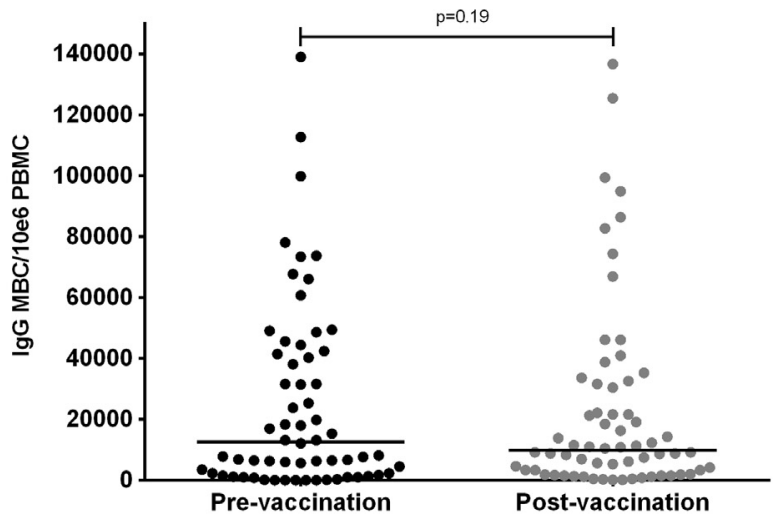

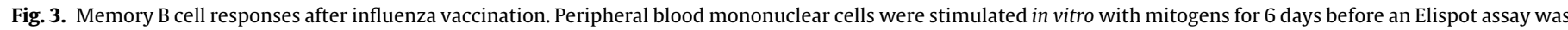

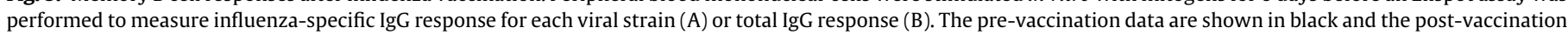
data in gray. Each dot represents one individual and bars show the median.

\subsection{Correlation between humoral and cellular responses}

We assessed the T-cell and B-cell immune responses in patients with or without an antibody response to each of the three influenza strains (Supplementary Table 1). Overall, we did not observe any significant differences between antibody vaccine responders and non-responders in terms of IFN- $\gamma$ median SFC, percentage of multifunctional specific CD4+ T cells, and specific IgG MBC responses for any of the three viral strains. Correlation between antibody titers and number of IgG SFC for each of the viral strains showed only weak non-significant correlation with the H3N2 strain, but not with the other strains (Supplementary Fig. 2).

\section{A. H1N1-specific IgG memory B-cell response}

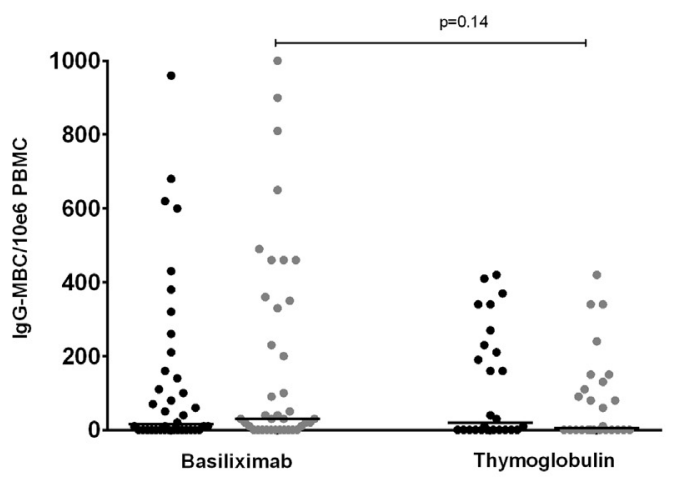

C. Influenza B-specific IgG memory B-cell response

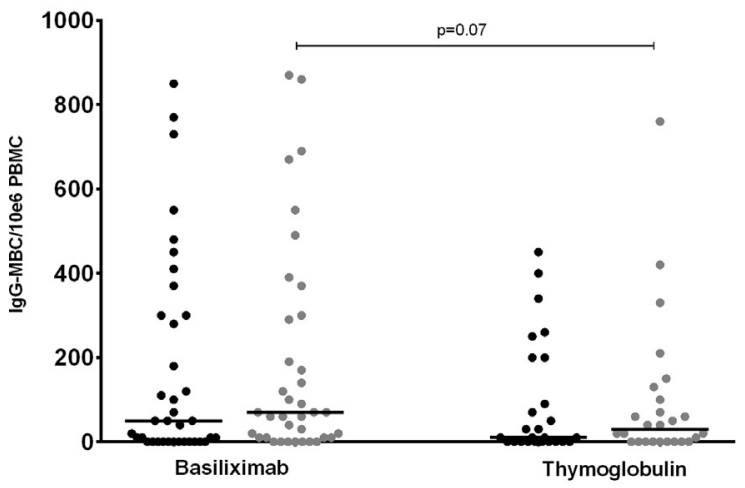

B.H3N2-specific IgG memory B-cell response

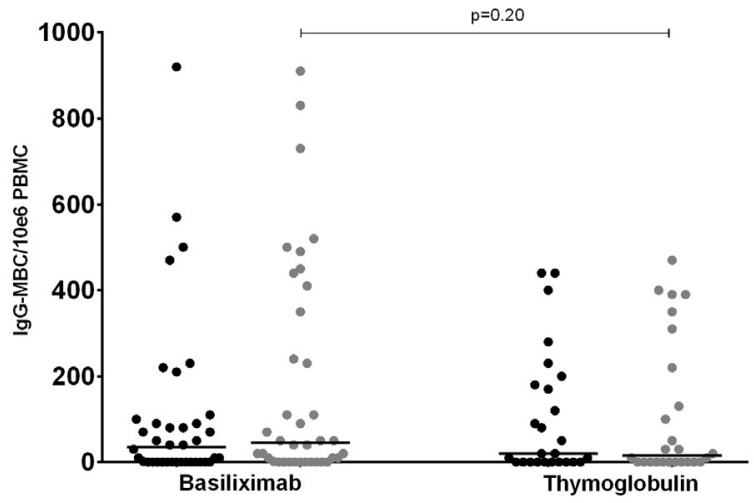

D.Total IgG memory B-cell response

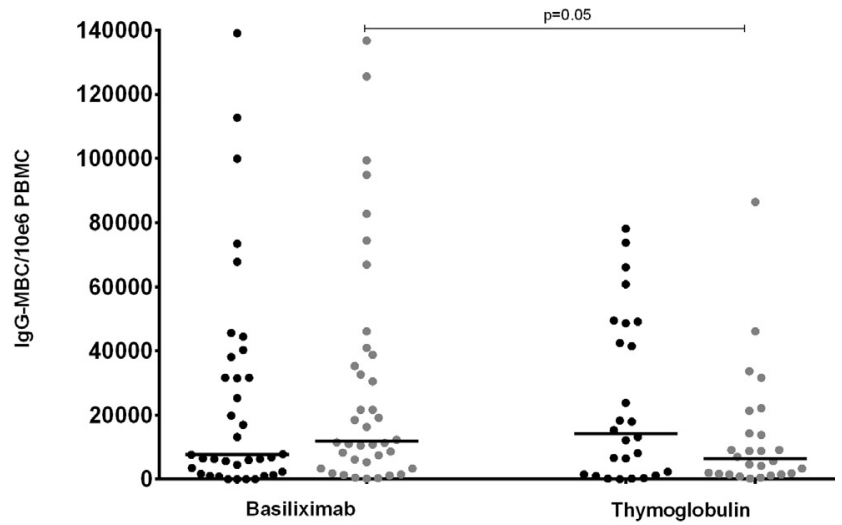

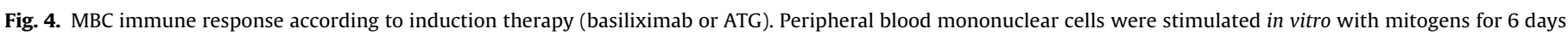

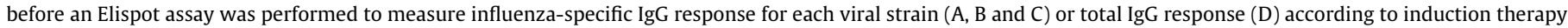

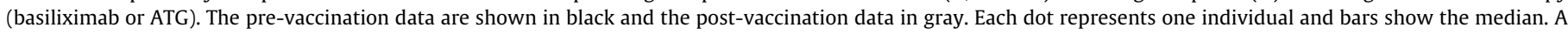
Mann-Whitney test was performed to attest of the statistical significance. 


\subsection{Influence of time from transplantation to vaccination on} immune responses

Overall, 22 patients were transplanted in the year preceding vaccination; 11 in the ATG group and 11 in the basiliximab group. Data on humoral and T-cell responses were available for 21 patients (11 ATG and 10 basiliximab). The Beyer corrected seroconversion rates were $45.5 \%$ for $\mathrm{H} 1 \mathrm{~N} 1,36.4 \%$ for $\mathrm{H} 3 \mathrm{~N} 2$ and $18.2 \%$ for influenza $B$ in the ATG group and $40 \%$ for H1N1, 50\% for H3N2 and $0 \%$ for influenza $\mathrm{B}$ in the basiliximab group $(p=0.87, p=0.38$, and $p=0.39$, respectively). No difference was seen in median IFN- $\gamma$ secretion 6 weeks after vaccination (60.0 SFC $/ 10^{6}$ PBMC for ATG and 60.6 $\mathrm{SFC} / 10^{6} \mathrm{PBMC}$ for basiliximab $[p=0.84]$ ). Regarding B-cell immune response analysis, data was available for 19 patients (10 in ATG and 9 basiliximab). Median IgG-MBC/106 PBMC were 5 for H1N1, 0 for $\mathrm{H} 3 \mathrm{~N} 2$ and 15 for influenza B in the ATG group and 10 for $\mathrm{H} 1 \mathrm{~N} 1,40$ for H3N2 and 70 for influenza B in the basiliximab group ( $p=0.91$, $p=0.31$, and $p=0.54$, respectively).

\section{Discussion}

In this cohort of SOT recipients we assessed the humoral and cellular immune responses after influenza vaccination in patients receiving two different types of anti T-cell therapies. We did not observed any significant difference between both therapies in terms of humoral, T-cell, and B-cell mediated immunity against influenza, independently of the time from transplant and other clinical parameters. A significant result of the study is the finding that influenza vaccination elicited rather appropriate antibody and Tcell responses. Also, we observed a poor memory B-cell response to the vaccine that was not correlated with previous use of the influenza vaccine.

According to previous studies, the immunogenicity of influenza vaccine is reduced in SOT recipients, with up to $15-70 \%$ of patients failing to respond to the vaccine, depending on the organ transplanted, the immunosuppressive regimen, and the time of vaccination after transplant [29-33]. In our study, previous administration of induction therapy had no impact on the influenza vaccine response (humoral and cellular) even though the CD4+ cell count was lower in the group that had received ATG. The similar antibody responses observed are in keeping with our previous study, where lymphocyte-depleting antibodies did not influence the antibody response to influenza vaccination [9]. This can be partially explained by the fact that we included stable SOT recipients, several months after transplantation, in whom the impact of a particular immunosuppressive drug could have been less evident than just after transplantation.

We observed a high seroprotection rate and a low seroconversion rate in our population, independent of the induction therapy received. This is most likely due to a high number of patients having detectable antibodies pre-vaccination, reflecting previous use of influenza vaccine in our patient cohort [30,34,35]. After taking into consideration the pre-vaccination titers [28], seroconversion rates increased up to $32-38 \%$ for influenza A strains, a rate near of the $40 \%$ seroconversion rate which is considered as appropriate for the general population $[9,36]$.

Specific T-cell and B-cell responses have also been implicated in protection against influenza [16]. However, characteristics of the cellular immune response to influenza vaccine in immunocompromised patients, such in SOT recipients $[4,23,37,38]$ are not widely reported. Because of lower CD4+ T-cell counts, we expected lower influenza specific T-cell mediated responses in patients receiving ATG, but this was not observed in our study. This can be partially explained by a lack of correlation between absolute CD4+ cell counts and the functional activity of these cells after antigenic stimulation. For example, in a cohort of kidney transplant recipients, the use of ATG was associated with the development of severe infections late after transplantation only in patients with impaired T-cell proliferation, but this was independent on the absolute numbers of CD4+ cells. Also, CD4+ cell counts were not associated with Il-2 expression or CD4 helper activity, supporting our data of an appropriate multifunctional specific T-cell response to influenza vaccine in patients with low CD4+ cell counts [7,39].

B-cell responses after influenza vaccination in immunocompromised patients have been insufficiently reported. In a prospective study involving 64 HIV-infected individuals, influenza vaccination elicited a poor $\mathrm{MBC}$ response, as compared to healthy volunteers. CD4+ T cell count in HIV-infected individuals was a critical determinant of this response [26]. These results agree with our study, where the $\mathrm{MBC}$ response was not enhanced after vaccination and was correlated with the $\mathrm{CD} 4+\mathrm{T}$-cell count. Interestingly, the baseline $\mathrm{MBC}$ response observed in this study was generally lower than what we observed in a cohort of healthcare workers [40]. It is unclear why the SOT recipients elicited a weak baseline MBC response, but previous studies identified the use of MPA as a responsible for a reduced HLA-DR expression on B cells after influenza vaccination [41]. Defective MBC responses were not observed in other studies including stable kidney transplant recipients [42] and HIV-infected children vaccinated against influenza [43].

One of the limitation of our study is that we did not include a control group of healthy volunteers or a group of transplant recipients that did not receive any induction therapy (at our center all patients receive induction therapy as per protocol) to compare the breadth of the vaccine immune responses; however, humoral and T-cell responses were consistent with those observed in previous studies in SOT recipients, and met the recommendations of European authorities. Also, we included a somewhat heterogeneous population in terms of transplant type and immunosuppressive regimens; we did not observe however differences in vaccine responses according to any specific drug. This could be also explained by the relatively modest sample size of our study. While we only evaluated one single time-point after vaccination, previous work has showed that a significant increase in blood MBC levels was observed between 27-42 days after influenza vaccination in healthy adults $[40,44]$.

In conclusion, our study showed that vaccination can induce influenza-specific humoral and T-cellular immunity in most kidney and heart transplant recipients. No correlation was found between humoral and cell-mediated immunity and no clinical factor influencing this response was identified. Because most patients were vaccinated years after transplant, the vaccine responses observed in our study might not be representative of all SOT recipients. More work will be necessary to further analyze this defective MBC response in transplant recipients.

\section{Authors' contribution}

D.H., M.P., R.P., R.C. and O.M. participated in the study design, acquisition and analyzing data, writing the article. S.L., G.B., K.H., R.H., P.M. participated in acquisition and analyzing data. All authors participated in critically reviewing the article.

\section{Funding}

This work was partially funded by an unrestricted grant from Roche.

\section{Conflict of interest}

The authors declare no conflicts of interest 


\section{Acknowledgments}

The authors thank the nursing staff and colleagues at the transplantation center of the CHUV for helpful assistance in the enrollment of patients. We thank Deolinda Alves for technical assistance. We also thank Glaxo SmithKline for supplying the split virus antigens used in this study.

\section{Appendix A. Supplementary data}

Supplementary material related to this article can be found, in the online version, at http://dx.doi.org/10.1016/j.vaccine.2016.05. 021.

\section{References}

[1] Cordero E, Manuel O. Influenza vaccination in solid-organ transplant recipients. Curr Opin Organ Transplant 2012;17:601-8.

[2] Kumar D, Michaels MG, Morris MI, Green M, Avery RK, Liu C, et al. Outcomes from pandemic influenza A H1N1 infection in recipients of solid-organ transplants: a multicentre cohort study. Lancet Infect Dis 2010;10:521-6.

[3] Kumar D, Blumberg EA, Danziger-Isakov L, Kotton CN, Halasa NB, Ison MG, et al. Influenza vaccination in the organ transplant recipient: review and summary recommendations. Am J Transplant 2011;11:2020-30.

[4] Candon S, Thervet E, Lebon P, Suberbielle C, Zuber J, Lima C, et al. Humoral and cellular immune responses after influenza vaccination in kidney transplant recipients. Am J Transplant 2009;9:2346-54.

[5] Brennan DC, Schnitzler MA. Long-term results of rabbit antithymocyte globulin and basiliximab induction. N Engl J Med 2008;359:1736-8.

[6] Manuel O, Venetz JP, Fellay J, Wasserfallen JB, Sturzenegger N, Fontana M, et al. Efficacy and safety of universal valganciclovir prophylaxis combined with a tacrolimus/mycophenolate-based regimen in kidney transplantation. Swiss Med Wkly 2007;137:669-76.

[7] Halloran PF. Immunosuppressive drugs for kidney transplantation. N Engl J Med 2004;351:2715-29.

[8] Sageshima J, Ciancio G, Guerra G, Gaynor JJ, Cova D, Zarak A, et al. Prolonged lymphocyte depletion by single-dose rabbit anti-thymocyte globulin and alemtuzumab in kidney transplantation. Transpl Immunol 2011;25:104-11.

[9] Orcurto A, Pascual M, Hoschler K, Aubert V, Meylan P, Manuel O. Impact of antiT-cell therapy in the immunogenicity of seasonal influenza vaccine in kidney transplant recipients. Transplantation 2012:94(6):630-6.

[10] Hobson D, Curry RL, Beare AS, Ward-Gardner A. The role of serum haemagglutination-inhibiting antibody in protection against challenge infection with influenza A2 and B viruses. J Hyg (Lond) 1972;70:767-77.

[11] Birdwell KA, Ikizler MR, Sannella EC, Wang L, Byrne DW, Ikizler TA, et al. Decreased antibody response to influenza vaccination in kidney transplant recipients: a prospective cohort study. Am J Kidney Dis 2009;54:112-21.

[12] Cox RJ. Correlates of protection to influenza virus, where do we go from here? Hum Vaccin Immunother 2013:9.

[13] McElhaney JE, Ewen C, Zhou X, Kane KP, Xie D, Hager WD, et al. Granzyme B: correlates with protection and enhanced CTL response to influenza vaccination in older adults. Vaccine 2009;27:2418-25.

[14] Sridhar S, Begom S, Bermingham A, Hoschler K, Adamson W, Carman W, et al. Cellular immune correlates of protection against symptomatic pandemic influenza. Nat Med 2013:19(10):1305-12.

[15] Pedersen GK, Madhun AS, Breakwell L, Hoschler K, Sjursen H, Pathirana RD, et al. T-helper 1 cells elicited by H5N1 vaccination predict seroprotection. J Infect Dis 2012:206:158-66.

[16] McElhaney JE, Xie D, Hager WD, Barry MB, Wang Y, Kleppinger A, et al. T cell responses are better correlates of vaccine protection in the elderly. J Immunol 2006;176:6333-9.

[17] Brown LE, Kelso A. Prospects for an influenza vaccine that induces crossprotective cytotoxic T lymphocytes. Immunol Cell Biol 2009;87:300-8.

[18] Crotty S, Aubert RD, Glidewell J, Ahmed R. Tracking human antigen-specific memory B cells: a sensitive and generalized ELISPOT system. J Immunol Methods 2004;286:111-22.

[19] Keshtkar-Jahromi M, Argani H, Rahnavardi M, Mirchi E, Atabak S, Tara SA, et al. Antibody response to influenza immunization in kidney transplant recipients receiving either azathioprine or mycophenolate: a controlled trial. Am J Nephrol 2008;28:654-60.

[20] Cordero E, Perez-Ordonez A, Aydillo TA, Torre-Cisneros J, Gavalda J, Lara R, et al. Therapy with m-TOR inhibitors decreases the response to the pandemic influenza A H1N1 vaccine in solid organ transplant recipients. Am J Transplant 2011;11:2205-13

[21] Ellis JS, Zambon MC. Molecular analysis of an outbreak of influenza in the United Kingdom. Eur J Epidemiol 1997;13:369-72.
[22] Czerkinsky C, Andersson G, Ekre HP, Nilsson LA, Klareskog L, Ouchterlony O. Reverse ELISPOT assay for clonal analysis of cytokine production. I. Enumeration of gamma-interferon-secreting cells. J Immunol Methods 1988;110:29-36

[23] Lindemann M, Witzke O, Lutkes P. Fiedler M, Kreuzfelder E, Philipp T, et al. ELISpot assay as a sensitive tool to detect cellular immunity following influenza vaccination in kidney transplant recipients. Clin Immunol 2006;120:342-8.

[24] Mohn KG, Bredholt G, Brokstad KA, Pathirana RD, Aarstad HJ, Tondel C, et al. Longevity of B-cell and T-cell responses after live attenuated influenza vaccination in children. J Infect Dis 2015;211(10):1541-9.

[25] Pedersen G, Halstensen A, Sjursen H, Naess A, Kristoffersen EK, Cox RJ. Pandemic influenza vaccination elicits influenza-specific CD4+ Th1-cell responses in hypogammaglobulinaemic patients: four case reports. Scand J Immunol 2011;74:210-8.

[26] Malaspina A, Moir S, Orsega SM, Vasquez J, Miller NJ, Donoghue ET, et al. Compromised B cell responses to influenza vaccination in HIV-infected individuals. J Infect Dis 2005;191:1442-50.

[27] European Agency for the Evaluation of Medicinal products/Committee for Proprietary Medicinal Products (CPMP). Note for guidance on harmonization of requirements for influenza vaccines. London E; 1997.

[28] Beyer WE, Palache AM, Luchters G, Nauta J, Osterhaus AD. Seroprotection rate, mean fold increase, seroconversion rate: which parameter adequately expresses seroresponse to influenza vaccination. Virus Res 2004:103:125-32.

[29] Soesman NM, Rimmelzwaan GF, Nieuwkoop NJ, Beyer WE, Tilanus HW, Kemmeren $\mathrm{MH}$, et al. Efficacy of influenza vaccination in adult liver transplant recipients. J Med Virol 2000;61:85-93.

[30] Scharpe J, Evenepoel P, Maes B, Bammens B, Claes K, Osterhaus AD, et al. Influenza vaccination is efficacious and safe in renal transplant recipients. Am J Transplant 2008;8:332-7.

[31] Manuel O, Humar A, Chen MH, Chernenko S, Singer LG, Cobos I, et al. Immunogenicity and safety of an intradermal boosting strategy for vaccination against influenza in lung transplant recipients. Am J Transplant 2007;7:2567-72.

[32] Baluch A, Humar A, Eurich D, Egli A, Liacini A, Hoschler K, et al. Randomized controlled trial of high-dose intradermal versus standard-dose intramuscular influenza vaccine in organ transplant recipients. Am J Transplant 2013;13:1026-33.

[33] Kumar D, Campbell P, Hoschler K, Hidalgo L, Al-Dabbagh M, Wilson L, et al. Randomized controlled trial of adjuvanted versus nonadjuvanted influenza vaccine in kidney transplant recipients. Transplantation 2016;100(3):662-9.

[34] Blumberg EA, Albano C, Pruett T, Isaacs R, Fitzpatrick J, Bergin J, et al. The immunogenicity of influenza virus vaccine in solid organ transplant recipients. Clin Infect Dis 1996;22:295-302.

[35] Cordero E, Aydillo TA, Perez-Ordonez A, Torre-Cisneros J, Lara R, Segura C, et al. Deficient long-term response to pandemic vaccine results in an insufficient antibody response to seasonal influenza vaccination in solid organ transplant recipients. Transplantation 2012;93:847-54.

[36] Manuel O, Pascual M, Hoschler K, Giulieri S, Alves D, Ellefsen K, et al. Humoral response to the influenza A H1N1/09 monovalent ASO3-adjuvanted vaccine in immunocompromised patients. Clin Infect Dis 2011;52:248-56.

[37] Madan RP, Tan M, Fernandez-Sesma A, Moran TM, Emre S, Campbell A, et al. A prospective, comparative study of the immune response to inactivated influenza vaccine in pediatric liver transplant recipients and their healthy siblings. Clin Infect Dis 2008;46:712-8.

[38] Le Corre N, Thibault F, Pouteil Noble C, Meiffredy V, Daoud S, Cahen R, et al. Effect of two injections of non-adjuvanted influenza A H1N1pdm2009 vaccine in renal transplant recipients: INSERM C09-32 TRANSFLUVAC trial. Vaccine 2012:30:7522-8

[39] Weimer R, Ettrich M, Renner F, Dietrich H, Susal C, Deisz S, et al. ATG induction in renal transplant recipients: Long-term hazard of severe infection is associated with long-term functional T cell impairment but not the ATG-induced CD4 cell decline. Hum Immunol 2014:75:561-9.

[40] Lartey S, Pathirana RD, Zhou F, Jul-Larsen A, Montomoli E, Wood J, et al. Single dose vaccination of the ASO3-adjuvanted A(H1N1)pdm09 monovalent vaccine in health care workers elicits homologous and cross-reactive cellular and humoral responses to H1N1 strains. Hum Vaccin Immunother 2015;11:1654-62.

[41] Egli A, Humar A, Widmer LA, Lisboa LF, Santer DM, Mueller T, et al. Effect of immunosuppression on T-helper 2 and B-cell responses to influenza vaccination. J. Infect. Dis 2015;212:137-46.

[42] Siegrist CA, van Delden C, Bel M, Combescure C, Delhumeau C, Cavassini M, et al. Higher memory responses in HIV-infected and kidney transplanted patients than in healthy subjects following priming with the pandemic vaccine. PLoS ONE 2012;7:e40428.

[43] Rinaldi S, Zangari P, Cotugno N, Manno EC, Brolatti N, Castrucci MR, et al. Antibody but not memory B-cell responses are tuned-down in vertically HIV1 infected children and young individuals being vaccinated yearly against influenza. Vaccine 2014;32:657-63.

[44] Sasaki S, Jaimes MC, Holmes TH, Dekker CL, Mahmood K, Kemble GW, et al. Comparison of the influenza virus-specific effector and memory B-cell responses to immunization of children and adults with live attenuated or inactivated influenza virus vaccines. J Virol 2007;81:215-28. 